\title{
COMPARISON REFURBISHMENT MODELS OF DISTRICT HEATING NETWORKS
}

\author{
Algirdas KUPRYS, Ramūnas GATAUTIS \\ Laboratory of energy systems research, Lithuanian Energy Institute, Breslaujos g. 3, \\ 44403 Kaunas, Lithuania
}

Received 7 Feb 2013; accepted 28 May 2013

\begin{abstract}
The renovation of multi-storey residential buildings reduces heat consumption intensity and decreases heat demand, which may have a harmful effect on a district heating supply system. The paper analyses the heat loss change in four district heating distribution networks (DHNs) of Kaunas at the various scenarios of buildings and DHN renovation stages. A bundle of genetic algorithm software package was used to carry out the districts' distribution network hydraulic calculations in the case of building renovation without changing the hydrodynamic and network routes. The experimental data were used to calculate heat loss for old and new pipes. The computer data of networks used to summarise the cost of DHN then for the renovation of buildings as well as for renovation progress will go evenly with DHN refurbishment. Network optimization results were summarised by functional dependence. The comparison of the projects' efficiency was analysed in the following cases: the diameters of pipes of DHN were not changed, new diameters of pipes were integrated partly after partial residential buildings renovation and after a complete renovation of residential building and optimisation of pipeline diameters. The efficiency of separate guidelines of the DHN refurbishment project was summarised by performing sensitivity analysis.
\end{abstract}

Keywords: buildings renovation, district heating network, heating cost, optimisation.

Reference to this paper should be made as follows: Kuprys, A.; Gatautis, R. 2014. Comparison refurbishment models of district heating networks, Journal of Civil Engineering and Management 20(1): 11-20.

http://dx.doi.org/10.3846/13923730.2013.812576

\section{Introduction}

The intensive multi-storey residential building construction began in the twentieth century, in the 1970s, and lasted about for 30 years in the largest Lithuanian cities. At that time, fuel (natural gas or heavy fuel oil) was regarded as a cheap resource, and the focus on increasing investment for saving energy to improve the insulation of district heating distribution network (DHN) pipes or buildings was considered not rationale.

The rising prices of fuel and, at the same time the price of heat, the consumption space heating for buildings needed during the cold period of the year over the past few decades marginally changed (the change of heat consumption increased with respect to construction or equipment wearing). As fuel prices continued to rise from year to year, the expenses of heat supply have become unacceptably high for DHN consumers.

The vast majority of the pipelines was installed 40 to 30 years ago, using existing technology, and now assessing the existing DHN heat loads and after long time exploitation the DHN are not adequate to meet the requirements today's needs. Figure 1 shows the heat losses in Lithuanian DHN and the percentage expenditures assigned to cover DHN thermal losses.

DHN thermal losses in Lithuania from 1996 decreased gradually and covered the amount of decreased expenses until 2006. Since 2006, fuel prices have drastically increased and defrayed expenses of DHN thermal losses grew faster than decreased thermal losses. Thus, decreasing heat amount for space heating and rising heat prices will continue to increase the expenses for heat consumption in DHN.

In the heating season 2011-2012, the renovated residential buildings' space heating records show that the renovated apartments approximately consume about 50\% less heat for space heating and hot tap water in buildings (Lithuanian District Heating Association 2012c). Considering this it can be said that if nothing is done for DHN renovation, the expenses to cover DHN heat losses will increase twice in case the fuel prices do not increase in the future. 
The objective of this study is the assistance of a bundle of genetic algorithm (GA) software package to explore several possible variations of buildings and DHN renovation processes as well as their combining possibilities and to comparing them. The bundle software package was used to carry out the districts' distribution of heating network hydraulic calculations in the case of building renovations without changing the hydrodynamic and network routes. A set of pipe diameters is selected directly from a specified set of commercial pipe diameters. In this article modelling DHN refurbishment is presented using four microdistricts of Kaunas city. Several criteria were used to compare the monetary volume for the period of renovation of DHN: total cost of heat losses, expenses for hot-water pump power and investments in the DHN.

\section{Review of previous research}

The demand for space heating and hot tap water in buildings is a major element of the total energy demand in many countries with moderate-to-cold climates. An increasing number of studies focus on the discussion of how the heat demand alteration in buildings may develop DHN in the future and alter to meet future thermal heat supply needs. The combination on the supply-side options of district heating, such as more efficient heat transportation technologies, and the demand-side options, such as the reduction of a building's heat demand through energy-efficient refurbishment, is receiving increasing attention.

In the literature, there are many studies on the different aspects of building insulation because there is a large potential for energy savings. Directive 2010/ 31/EU (2010) on the energy performance of buildings set minimum energy efficiency requirements for new and renovated buildings and is promoting greater energy efficiency in buildings according to the local climate. It was to introduce energy certification to guarantee a future uniformity in the European building stock. The uniformity of results effected by the problem that the Standards (EN ISO 13790:2008) leave to the technician many possibilities to choose input data and calculation methodologies with the consequence of a non-univocal definition of the building energy performance.

The Government of the Republic of Lithuania constantly improves laws to encourage renovation of blocks of flats. For example in 2011, it adapted a resolution on public support for multi-storey residential buildings' renovation project monitoring the implementation of rules for approval and apartment renovation (modernisation) project for cumulative contribution. One main reason is the lack of transparency in the building modernisation process and society cannot receive any tangible guaranties that the declared energy saving benefits will be actually reached (Biekša et al. 2011). Currently, the residential buildings' renovation programme has not yet received the necessary acceleration for fully resolving the legal and economic issues, and it is likely that in the nearest perspective, it will get proper acceleration.

The last approaches (Entrop et al. 2010; Asadi et al. 2012) of energy optimisation in buildings use the application of multi-objective optimisation characterized by the existence of multiple and competing objectives. The calculation method (Magrini et al. 2012) compares the energy performance of different buildings and gives the definition of an indicator of energy performance of buildings. The results of the energy calculations of buildings (Konstantinou, Knaack 2011) are integrated into the toolbox (determined the specifications for the construction details), which it then re-organises according to the efficiency of the measure, starting from the existing situation and scaling up to the impact they have on the energy demand for heating. The toolbox calculations provide an indication of how effective the separate measures can be.

The implementation of residential buildings' renovation programmes leads to a decrease in the consumption of heat supply amount to buildings and is one of the factors of DHN pipeline modernisation. The pipelines' refurbishment is a capital-intensive process, so the rational scale renovation and the search for the priorities of pipeline renovation are very important.

The heat loss reduction problems of HD networks are commonly known as optimisation of network pipeline insulation. The technical and economic feasibility has been investigated for twin (Basogul, Keçebas 2011) and triple (Dalla Rosa, Christensen 2011) pipe system geometries of DHN network, pipe sizes or district heating water (DHW) quantity variation. The use of smaller pipe sizes was achieved by allowing a high-pressure gradient in the pipelines and above all in the branch pipes connected to the unit with instantaneous DHW preparation (Dalla Rosa, Svendsen 2011). Installing units with water storage of DHN (Paulsen et al. 2008), where water storage tank coupled with a heat exchanger on the primary side, ensures low continuous water flow of the DHN network and, therefore, low-size medium pipes in house connections and low DHN temperatures: $50-55^{\circ} \mathrm{C}$ in the supply line and $20-25^{\circ} \mathrm{C}$ in the return line. The use lowers water parameters for DHN down to $50-85^{\circ} \mathrm{C}$ in the supply and about $20-25^{\circ} \mathrm{C}$ in the return line and is presented in the studies of Dalla Rosa and Christensen (2011) and Tol and Svendsen (2012). The technical and economic feasibility study of such systems is investigated from the theoretical point of view of Olsen et al. (2008) and applied by Svendsen and Brand (2010). Lowering the supply and return temperatures increases the final energy efficiency of 
the systems (Torío, Schmidt 2010) and decreases the distribution heat losses (Svendsen, Brand 2010).

The following measures lead to both lower investment costs for the civil works connected to the laying of the pipelines and lower heat loss. The use of low-level parameters of heating water for DHN allows using plastic pipelines rather than a pair of single steel pipes.

Besides the DHN system's hydraulic modelling tasks, it is necessary to include network optimisation as well. The DHN optimum pipes' diameters and routes determination are based on economic analysis and district heating system load analysis. The models of network optimization are designed for different purposes and, therefore, have different properties as well as application areas. Because of this, optimisation modelling must include calculations with discrete variables - pipe diameters and hydraulic pumps with non-linear characteristics. Nowadays, the DHN distribution networks' optimisation tasks are resolved with linear (Jamsek et al. 2010; Mehleri et al. 2012) and non-linear programming (Li et al. 2010; Dobersek et al. 2012). Comparison of the linear and GA ascertains that the GA gives better results ( $\mathrm{Li}$ et al. 2010). GA operators selected to reduce the calculation time and obtain good calculation accuracy. This method is used to design commercial DHN when the route network is known.

The above studies show in general that the reduction of buildings' heat demand can go in conjunction with the refurbishment of DHN and improves the efficiency of energy systems. The results show that end-use energy savings and district heating expansion are combined in the existing energy system to improve the overall fuel efficiency of the system. Therefore, we chose a bundle of GA software: EPANET and OptiWater (Ostfeld, Salomons 2004) to perform the DHN hydraulic calculations and optimisation. These software packages allowed to optimise the pipes' diameters, depending on the amount of supply of hot water to the consumers at constant pressure and variation of flow rate.

\section{Data collections}

The multi-storey residential buildings built at different times contain the different thermal characteristics of buildings, as well as the DHN pipelines and its wearing rate. The order to assess the differences or the similarities of heat consumption among different parts of the city districts was selected for four districts built in different periods. The main data of the selected districts are presented in Table 1.

The four districts of Kaunas city, one of Dainava, two of Kalnieciai and one of Silainiai, receive hot water from city DHN's different branches. The pipeline network in the micro-districts is a two-pipe mode with directly buried installation in impenetrable channels. The following DHN technical data of microdistricts collected the following: maps of DHN pipes routes, pressures at the gate valve of junction node to the micro-district, pipe diameters and lengths, installed heat capacities of blockhouses for space heating and tap hot water, thermal insulation, old and new commercially available pipes, and pipes' heat losses before and after renovation of DHN, etc.

\section{DHN optimisation options}

Nowadays, the multi-storey residential buildings' renovation processes in Lithuania have no coordination in principle. According to the current order, the residential buildings are renovated due to the initiative of house community. Currently, the renovations of residential buildings of the whole district are not planned. Generally, such a renovation process can be described as random. According to the stage of buildings' renovation in the urban micro-district, the following scenarios of heat consumptions in multistorey residential buildings and heat losses in pipelines were examined:

(1) The buildings and DHN pipelines are not renewed.

(2) The buildings are not renewed and the DHN pipelines are renewed without changing the pipe diameters.

(3) House is renewed randomly. Random number generator is used for selecting the buildings for renovations.

(4) All district buildings are renovated in a relatively short period. The DHN piping system is also renovated at the same time to assess the new demand of heat consumption.

Table 1. Main data of urban blocks for consideration

\begin{tabular}{|c|c|c|c|c|c|}
\hline \multicolumn{2}{|c|}{ The name of Kaunas city micro-district } & \multirow{2}{*}{$\frac{\text { Dainava }}{\mathrm{T}-5}$} & \multirow{2}{*}{$\frac{\text { Kalniečiai I }}{\mathrm{T}-37-21}$} & \multirow{2}{*}{$\frac{\text { Kalniečiai II }}{\mathrm{T}-28-1}$} & \multirow{2}{*}{$\frac{\text { Šilainiai }}{83 \mathrm{Z}}$} \\
\hline DHN gate valve labelling & & & & & \\
\hline & Beginning & 1973 & 1982 & 1975 & 1983 \\
\hline District building period & Ending & 1987 & 1984 & 1979 & 1987 \\
\hline $\begin{array}{l}\text { Number of residential blo } \\
\text { buildings }\end{array}$ & & 34 & 11 & 15 & 21 \\
\hline \multirow[t]{2}{*}{ DHN length (m) } & & 3350 & 807 & 1136 & 1593 \\
\hline & For space heating & 0.270 & 0.354 & 0.295 & 0.278 \\
\hline Installed capacity (MW) & For tap hot water & 0.266 & 0.239 & 0.195 & 0.246 \\
\hline
\end{tabular}


Four scenarios of urban blocks of renovated buildings were examined according to the sum of the renovated buildings. The sum of renovated buildings depends on the figures of random number generator which is between $0-0.25 ; 0-0.50 ; 0-0.75$; and $0-1.0$. The pipelines were renewed gradually assessing the alteration of decline in the building's heating needs. The best pipe diameters are calculated.

\section{Methodology}

Energy price in cities for heating is determined by the State for Prices and Energy Control Commission. This price is relatively divided into variable and constant costs. Variable costs include fuel, purchased heat, electricity and water technology costs, which vary depending on the required, manufactured and supplied heat transfer rate of heat networks. Fixed costs are those costs that the company has irrespective of the heat produced and delivered to customer's heat amount. They include depreciation, earnings and social insurance fee, repairs and other services, taxing, interest, etc. Usually, simplified methods are used to calculate district heating price. The optimisation function usually computes the network minimum cost sum $C_{\min }$ of DHN (Persson, Werner 2011; Mehleri et al. 2012):

$$
C_{\min }=C_{h}+C_{p}+C_{c}+C_{m},
$$

where: $C_{h}$ is the expense related to heat loss in DHN; $C_{p}$ is the expense for hot water pump power; $C_{c}$ is DHN capital investment; and $C_{m}$ is the operating expense.

The basic goal of heat supply is to ensure reliable heat supply to consumers at any ambient air temperature and at maximum demand of domestic hot water needs. As the largest part of the heat supplied to consumers consumed for heating purposes is sufficient to confine heat regulation, the DHN heat suppliers regulate the heat supply, changing the coolant temperature at the same coolant flow, when the heat consumer's ability to regulate heat supply itself is limited. The essence of regulation is that the heat supply and heating system circulate coolant flow rate constant and entrained heat flow controlled by changing the heat source, the flow temperature. Some buildings are equipped with old thermal substations, which regulate heating water supply to the user's system at constant pressure. Improper selection of inlet pressures may cause heat supply disturbances to consumers. In addition, the water velocity in pipes must be within certain limits for technical requirements (Eqn (2)):

$$
\Delta p_{\min } \leq \Delta p_{n, k} \leq \Delta p_{\max }, v_{\min } \leq v_{i} \leq v_{\max }
$$

where: $p$ is the pressure; $n$ is end node of the branch; $k$ is the number of branch; $v$ is the hot water speed in the pipe; $i$ is the pipe number; and min and max are the values of minimum and maximum.

At a building thermal substation, inlet pressure is the following:

$$
\Delta p_{n, k}=\sum_{i=1}^{n} \Delta p_{i, k}
$$

By assuming that the known inflow and outflow pressure of hot water into micro-district distribution DHN is best from the real measurements of the existing network of routes in the urban block and they have not changed, the calculations are made for the district heating distribution network when, by the way of reconstruction period, hot water maximum velocity and pressure differences between the pipes of the network shall not exceed the current maximum and minimum values.

The operating costs were not included in our investigation of the network calculations due to lack of data. Thus, in this work, for purposes of optimisation, DHN was restricted only to variables of expenditures related to heat losses, water pump power and capital expenditures for refurbishment of distribution networks.

Without measured data, the standard method was used to calculate the quantity of hot water (STR 2.09.01:1998). The quantities of hot water were calculated for multi-storey residential buildings. We used an expired regulatory document (STR 2.09.01: 1998) because the multi-storey residential buildings were built during the time of validity of this document. The following formula was used to calculate total amount of hot water for two pipes of the DHN system:

$$
G_{\text {sum }}=G_{s}+G_{d}
$$

where: $G_{s}$ is the maximum hot water amount for space heating and $G_{d}$ is the maximum hot water amount required for tap hot water preparation.

This hot water amount was calculated in accordance with the installed thermal power of buildings (from the buildings technical passports):

$$
G_{s}=\frac{\sum_{i=1}^{n} Q_{s, i}}{c\left(\tau_{1}-\tau_{2}\right)} ; G_{d}=\frac{\sum_{i=1}^{n} Q_{d, i}}{c\left(t_{h}-t_{c}\right)},
$$

where: $Q_{s}$ and $Q_{d}$ are the installed capacities of building's space heating and tap hot water; $c$ is the specific heat of water; $\tau_{1}$ is the feeding hot water temperature; $\tau_{2}$ is the hot water return temperature; $t_{h}$ is the tap hot water temperature for domestic needs; and $t_{c}$ is the average temperature of cold water.

From the known inflow and outflow pressure data of hot water into micro-district distribution, 
DHN hot water hydraulic pressure is $\Delta p$ and the electricity cost for pumping of a centrifugal pump is:

$$
C_{p}=\left(g \Delta p c_{e} G_{\text {sum }} \tau \rho\right) /\left(\eta_{p} \eta_{c}\right)
$$

where: $g$ is the standard acceleration of gravity; $\Delta p$ is the pressure at the gate valve at a junction node to micro-district; $c_{e}$ is the price of electricity; $\tau$ is the pump working time per year; $\rho$ is the water specific volume (presumed constant); $\eta_{p}$ is the average pump efficiency and $\eta_{c}$ is pump cost share of electricity from pump capital expenditures of the total pump cost.

The figures of hot water quantities (Eqn (4)), equivalent pipe lengths (Eqn (7)) and initial pressure inflow and outflow of hot water pressures at junction node into micro-DHN were used to calculate water debits and pressures in DHN nodes. Equivalent pipe length $L_{H}$ was calculated by Eqn (7) including terms of minor resistance coefficients:

$$
L_{H}=D \times \frac{\sum_{i=1}^{n} K_{L, i}}{f}+L,
$$

where: $L$ is the pipe length; $D$ is the pipe hydraulic diameter; $K$ is the resistance coefficient; and $f$ is the friction factor that is applied to the entire pipe.

Hot water flow rates and pressures simulate aid of EPANET2 software. The maximum and minimum pressure at nodes and water velocity values in pipes were obtained from DHN hydraulic calculations. For further calculations, these values were used as limitary values to optimise the pipeline network diameters.

The DHN pipe diameters were computed by minimising the expenses from DHN heat losses and capital investment costs of the form of a functional with $i$ pipeline collection:

$C=\sum_{i=1}^{m}\left(Q_{i} T L_{i} S+P_{i} L_{i}\right)+C_{p}=\min , i=1,2, \ldots, m$,

where: $Q$ is the heat loss per year; $T$ is the tariff of hot water; $S$ is the pipes lifetime; $P$ is the pipe capital investment of new pipes construction replacement cost; $L$ is the pipe length and $m$ is total pipes' number of renovated DHN.

The optiWater software GA was used to minimise functional Eqn (8). The following DHN calculation options were performed: the DHN heat loss calculations for micro-districts with existing pipelines. The heat loss costs were calculated without optimisation and with the existing pipe diameters. These calculation results were used as a starting point for assessment pressures and velocity values of the DHN for estimating heat loss reduction and electricity cost reduction for pumping of a centrifugal pump. The resulting minimum and maximum values (Eqn (2)) were used as the limits of optimised pipe diameters for calculation (Eqn (8)); the pipe diameters were optimised when the buildings were not renewed. This calculation is carried out to assess whether the used methodology adequately reflects the assumptions of the existing networks.

For partial renovation of DHN, we presume that multi-storey residential buildings in a micro-district region's DHN and pipelines will be renovated similarly. DHN pipelines will be renovated up to pipes interlink with the pipeline branches which is connected to the non-renovated multi-storey residential buildings. The pipes' capital investment costs in the 2006 data of Kaunas DHN were used to evaluate the investments costs of new pipes construction replacement.

\section{The results}

To make sure that our current issues of DHN pipes' diameters selected are optimal (Eqns (5) and (8)), we performed the network calculations when renovation of buildings and pipelines were not up to date and calculations were carried out with the old pipe insulation.

These calculations showed that the overall results of the discrepancies do not exceed $13 \%$ and are near the best design of pipe diameters (Table 2), which enables to confirm that the discrepancies are minor and calculations are adequate. In addition, these results showed that the DHN installed 30-40 years ago adequately reflect the current price level (expenses related to heat loss in DHN, capital investment) though it increased during this period many times.

The total DHN alteration of installed capacity is given in Figure 3 depending on the quantity of the renovated buildings. Therefore, the renovated buildings were selected randomly using a random number generator, and for each urban district, they were assigned the random number of sets. The random number between $0-0.25 ; 0-0.50 ; 0-0.75$; and $0-1.0$ was assigned to each blockhouse considering the number of the renovated buildings. Depending on the number of randomly renovated buildings, DHN water flow was gradually changed. It is obvious that in the process of building renovation there was a decrease in hot water consumption in the microdistrict and at the same time where it is possible pipes

Table 2. Comparison of DHN heat losses

Denotation Optimised, Current, kW/

of DHN $\quad \mathrm{kW} /(\mathrm{m}$. year) (m. year) Discrepancy $(\%)$

\begin{tabular}{lccr}
\hline TT-28 & 78.4 & 78.8 & 0.6 \\
$1 \mathrm{~T}-37$ & 46.5 & 53.4 & 13.0 \\
$38 \mathrm{Z}$ & 96.3 & 100.4 & 4.2 \\
$1 \mathrm{~T}-5$ & 200 & 217 & 7.8 \\
Total & 422 & 450 & 6.2 \\
\hline
\end{tabular}


will be replaced. Figure 2 shows an alteration of DHN heat losses depending on the share of the renovated buildings.

The assessment trends of the costs in the district heating sector show that the district heating supply costs are higher than or about the same level of the heat demand reduction measures.

After the complete renovation of the analysed four DHN distributing networks, the total energy saving is up to $67 \%$ and district buildings' reduced energy saving is up to $40 \%$. The random buildings renovation and the parallel refurbishment of the DHN and heat loss reduction $(Y)$ from the installed DHN capacity $(X)$ are assessed from the following equation:

$$
Y=2.930 X^{2}+0.5268 X, \% .
$$

Equation (9) shows a small dispersion of data (correlation coefficient $R=0.97$ ) as well as the fact that DHN heat loss reduction rate is independent of the district size and independent at a time when a district is built (these variables due to the low significance in this regression equation is not assessed). Such gradual renovation of DHN scenario gives positive results of energy saving but is hardly acceptable because at the beginning of buildings' renovation in the district, a small renovated house's energy share savings in DHN is negligible. This is due to the initial phase of home renovation, and DHN refurbishment can be accomplished only near the inlets to the house. When the number of renovated homes increases throughout the micro-district and, at the same time, increases the potential to develop DHN renovation where the pipe diameter is larger, the same heat saving effect is more significant. Also random home renovation scenarios may be delayed in the long period and constant partial update DHN bay disturbs the infrastructure of the district. Such DHN modernisation scenario can hardly be acceptable due to the low thermal efficiency of energy economy and constant inconvenience to residents on account of the uninterrupted ongoing earthworks.

\section{DHN refurbishment alternatives}

The DHN renovation scenario is much preferable where the renovation of multi-storey residential buildings and network is carried out at once. This can be distinguished from the two cases for DHN refurbishment: when the blockhouses of the entire district is fully renovated or not renovated. The data of the twoboundary cases are presented in the DHN investment in Table 3 - (A) without district buildings renovation and DHN optimisation and (B) after complete district buildings renovation and DHN optimisation.

Investments to refurbishment four micro district of Kaunas DHNs include optimized pipes routes and diameters. The data of capital investment costs of new

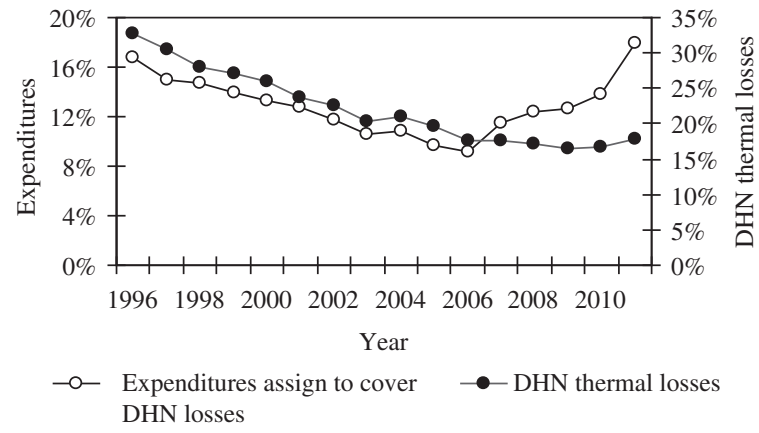

Fig. 1. Expenditures assigned to cover DHN losses and DHN thermal losses in Lithuania (Lithuanian District Heating Association 2012b)

pipes deliver to us Joint Stock Company Kaunas energy. The network heat losses were calculated using the data of Kaunas DHN pipes' heat loss. The investment and heat loss values for replaced DHN are presented in Table 4.

In our case, standard deviation shows that the data are very close to the mean and correlation coefficient is close to 1.0. The figures shown in Table 4 of standard deviations and correlation coefficients of investments and heat losses expense of DHN are equivalent and are not a necessary estimate to assess the district area separately. Therefore, to compare the investments in the projects of DHN refurbishment, we can use mean values of investments and heat loss expenses from Table 4.

Net present worth (NPW) is an evaluation method used by financial managers to determine the overall value of a project. When the NPW is positive, the investment results in a rate of return are greater than the minimum acceptable rate of return (MARR). When the NPW is zero, the investment returns are exactly the MARR, and this too would show a precarious investment. When the NPW is negative, the investment would not satisfy the requirement of

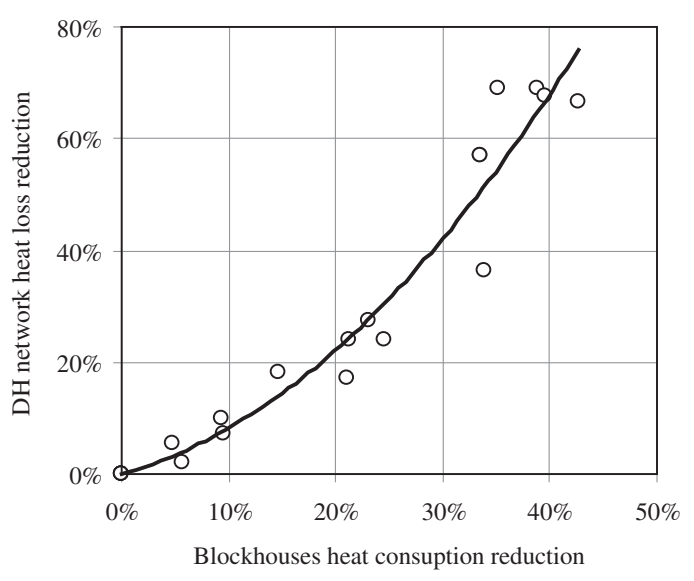

Fig. 2. DHN heat reductions from renovating district buildings' heat consumption 
Table 3. Investments and heat losses of DHN

\begin{tabular}{|c|c|c|c|c|c|c|}
\hline & & & \multicolumn{4}{|c|}{ Micro-district labelling } \\
\hline \multicolumn{3}{|c|}{ Denotation of DHN gate valve } & $\mathrm{T}-5$ & T-28-1 & $1 \mathrm{~T}-37-21$ & $38 \mathrm{Z}$ \\
\hline \multirow{3}{*}{\multicolumn{2}{|c|}{$\begin{array}{l}\text { Installed capacity of buildings (MW) } \\
\text { DHN pipe length (m) }\end{array}$}} & A & 12.94 & 7.36 & 6.53 & 9.90 \\
\hline & & $\mathrm{B}$ & 7.41 & 4.90 & 3.99 & 5.99 \\
\hline & & & 3340 & 3350 & 1136 & 807 \\
\hline \multirow[t]{2}{*}{ Investments in DHN (million Lt) } & A & $X_{1}$ & 3.45 & 1.313 & 0.856 & 1.650 \\
\hline & B & $X_{2}$ & 2.84 & 1.094 & 0.631 & 1.269 \\
\hline \multirow[t]{3}{*}{ The DHN heat losses (kWh/a) } & Old pipes & $X_{3}$ & 231.3 & 79.7 & 54.3 & 101.4 \\
\hline & A & $X_{4}$ & 89.7 & 31.0 & 21.0 & 39.4 \\
\hline & $\mathrm{B}$ & $X_{5}$ & 77.2 & 28.0 & 17.8 & 34.2 \\
\hline
\end{tabular}

Table 4. Investments and heat loss expenses of DHN

\begin{tabular}{|c|c|c|c|c|c|}
\hline \multirow[b]{2}{*}{ Denotation of DHN } & \multicolumn{2}{|c|}{ Investments $(\mathrm{Lt} / \mathrm{m})$} & \multicolumn{3}{|c|}{ Heat loss expenses $(\mathrm{Lt} /(\mathrm{m}$. year $))$} \\
\hline & $X_{1}$ & $X_{2}$ & $X_{3}$ & $X_{4}$ & $X_{5}$ \\
\hline $\mathrm{T}-5$ & 1.056 & 0.899 & 0.152 & 0.058 & 0.050 \\
\hline T-28-1 & 1.206 & 1.011 & 0.124 & 0.058 & 0.052 \\
\hline $\mathrm{T}-37-21$ & 1.081 & 0.835 & 0.145 & 0.056 & 0.054 \\
\hline $38 \mathrm{Z}$ & 1.036 & 0.820 & 0.139 & 0.054 & 0.045 \\
\hline $\bar{X}_{i}$ & 1.094 & 0.891 & 0.140 & 0.057 & 0.050 \\
\hline$\sigma\left(X_{i}\right)$ & 0.076 & 0.087 & 0.012 & 0.002 & 0.004 \\
\hline$r\left(X_{i}\right)$ & 0.997 & 0.995 & 0.998 & 0.998 & 0.997 \\
\hline
\end{tabular}

Note: Denotation: $X_{i}, i=1,2, \ldots, 5$ as in Table $3 ; \bar{X}$ - mean; $\sigma$ - standard deviation; $r$ - correlation coefficient.

the minimum rate and should be rejected. The next type of equation solved:

$$
\mathrm{NPW}=-P+\sum_{t=1}^{n} \frac{\left(I_{t}-C_{t}\right)}{(1+i)^{t}}
$$

where: $P$ is investment; $I$ is income; $C$ is expenses; $t$ is annual period; and $i$ is MARR.

The effectiveness of DHN refurbishment replacing old pipes with new was evaluated with the assistance of OR/IM software package. It is expedient for project evaluation that NPW was used when the cash flows associated with several competing alternatives vary over time. Alternatives may be compared with the present worth method or the annual worth method. For the present worth method, the NPW of the cash flows for each alternative $k$ is computed using the MARR. Three alternatives were considered for DHN refurbishment. The first alternative is donothing (DN) option and usually is the alternative when the evaluation is performed. Selection of the DN alternative means that the current approach is that no new costs, revenues or savings are generated. Two other alternatives are optimisation of DHN refurbishment without district buildings renovation - case $\mathrm{A}$, and after complete district buildings renovation case B (Tables 3 and 4). The comparison is made at the same MARR. This alternative is presented in Table 5 - construction of new pipes without changing pipe diameters and DHN are distributing network pipe replacement after pipe diameters optimisation, taking in mind the complete buildings' renovation.

For comparison, two projects of DHN refurbishment $\mathrm{A}$ and $\mathrm{B}$ and the investments for replacing pipes used mean values from Table 4. Value added tax (VAT) is used at reduced rate in Lithuania for space heating and now it is 9\%. As Eqn (10) is a function of time, it is necessary to take into account the overall inflation, heat prices and tax growth. To calculate the NPW, it is presumed that the general inflation rate in Lithuania is equal to the average inflation rate of the previous 16 years (Statistics Lithuania 2013). From 1 December 2011, the National Control Commission for Prices and Energy adapted heating price in Kaunas city as 29.24 Lt/MWh without VAT. The forecast of heat energy price was presumed as an average of 1996 2011 annual heating price growth (inflation) (Lithuanian District Heating Association 2012a). Since Eqn (10) is a function of time, the NPW evaluation of all economic indicators was adapted in the same average as of 1996 to 2011 annual level. After the refurbishment of DHN, the revenue calculated as the difference of heat losses expense from old pipes (case DN Table 4) and DHN new installed pipes. Revenue after DHN renovation is calculated as the cost difference between the heat losses plated for the case A and for case B from Table 4.

The difference between payback periods among projects A and B is 2.2 year. Table 5 shows that there is 
Table 5. Two projects' comparison of DHN refurbishment

\begin{tabular}{lccc}
\hline Project & A & B \\
\hline Investments (Lt/m) & 1.094 & & 0.891 \\
VAT (\%) & & 9 & \\
Overall inflation (\%) & 3.65 & & \\
Revenue (Lt/(m. year)) & 0.083 & & 0.090 \\
Heating price inflation (\%) & \multicolumn{2}{c}{8.28} \\
MARR (\%) & 10 & 10 & 13 \\
IRR (\%) & 10.8 & & 8.6 \\
Payback period (year) & & & \\
\hline
\end{tabular}

a significant difference, and project B is more acceptable.

Continuously rising fuel prices increase the prices on energy resources, and this is a serious challenge to the expenses related to heat loss in DHN. In addition, some other variables, such as overall inflation, DHN lifetime, etc., may have a significant impact on the variation of NPW.

The analysis of uncertainty is based on statistical thinking. The general model, which forms the basis of various classical statistical models, is the model which posits that measurement can be interpreted adding together the values of deterministic $(Y)$ and component $(\sigma)$ to estimate the output quantity:

$$
Y^{\prime}=Y \pm \sigma .
$$

The uncertainty evaluation process could be at any level required, depending on the application. In this paper, uncertainty is equal standard deviation (Cox, Harris 2006). The overall inflation and heating price inflation at a time horizon of 15 years were evaluated using Eqn (11). The revenue was evaluated after complete DHN renovation according to Table 4. The range of values' variation of VAT and DHN lifetime as accepted by authors is presented in Table 6 .

The figures shown in Table 6 are used to evaluate the uncertainty of NPW according "tornado" diagram. The 'tornado' diagram (Fig. 3) shows the influence of various parameters (variables) for the reconstruction of DHN. This chart graphically shows the result of single factors influence for the outcome of the solution, when other variables are basic (mean) values. For each of the uncertain decision parameters, the chart contains one horizontal bar and two sets of numbers, one of the left and the other to the right of the bar. Each set

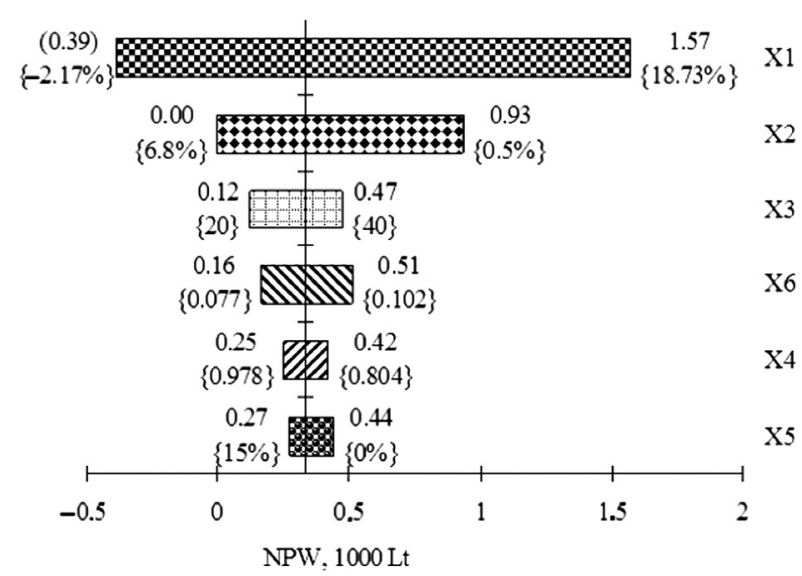

Fig. 3. Variables' evaluation of NPW. Denotation is shown in Table 6

of numbers corresponds to the result of NPW value (upper number) and the value of the parameter at which the result value was reached (the lower number within curly brackets). Negative numbers are shown in parenthesis. The lower numbers within curly brackets are the data from Table 6 presented in curly brackets in Figure 3.

The NPW was calculated from Eqn (10) bearing in mind Eqn (11) and data from Table 6. The greatest influence on the instability of NPW has heating price variation. The next greatest uncertainly component is overall inflation in the country.

It is obvious that all variables presented in Figure 3 can operate together in influencing the NPW. Here, NPW is convenient for evaluating the interaction among the variables by multiple regression Eqn (12):

$$
\begin{aligned}
\mathrm{NPW}= & -0.909+177 Y_{6} Y_{1}-178 Y_{2} Y_{1} \\
& +0.0176 Y_{3} .
\end{aligned}
$$

The multiple correlation coefficient $(R)$ among predicted value NPW and the actual NPW are $R=$ 0.97. Thus, NPW with great accuracy can be predicted from the set of $Y_{i}$ figures. Variables $Y_{4}$ and $Y_{5}$ are neglected in Eqn. (12) due to low influence.

\section{Conclusions}

The optimisation data of hydraulic results allow the possibilities to explore DHN and multi-storey residential

\begin{tabular}{|c|c|c|c|c|c|}
\hline Values for evaluation & No. & Dimension & Mean & Min & Max \\
\hline Heating price inflation & $Y_{1}$ & $\%$ & 8.3 & -2.2 & 18.7 \\
\hline Overall inflation & $Y_{2}$ & $\%$ & 3.6 & 0.5 & 6.8 \\
\hline Network lifetime & $Y_{3}$ & Year & 30 & 20 & 40 \\
\hline Investments $\bar{X}_{2} \mp \sigma\left(X_{2}\right)$ (Table 4) & $Y_{4}$ & $1000 \mathrm{Lt} / \mathrm{m}$ & 0.891 & 0.804 & 0.978 \\
\hline VAT & $Y_{5}$ & $\%$ & 9 & 0 & 15 \\
\hline Revenue $\overline{X_{3}-X_{5}} \mp \sigma\left(X_{3}-X_{5}\right)$ (Table 4) & $Y_{6}$ & $1000 \mathrm{Lt} /(\mathrm{m}$. year $)$ & 0.090 & 0.077 & 0.102 \\
\hline
\end{tabular}
building renovation at its various stages of refurbishment.

Table 6. Values to evaluate the uncertainty of NPW (DHN after complete district renovation - case B) 
The following scenarios of the residential buildings and DHN refurbishment were investigated:

(1) The multi-storey residential buildings and DHN are renovated simultaneously. The regression equation obtained subject to DHN heat decline from the amount of multi-storey residential building renovation show that the random renovation at the beginning stages of multi-storey residential buildings and the pipeline renovation do not have significant effect on saving heating energy in DNH. After the complete renovation, the total energy saving for DHN distributing networks is up to $67 \%$, while the renovation of micro-district buildings reduces the energy saving up to $40 \%$.

(2) The two-boundary cases' data are presented by DHN investment without district building renovation and after complete district building renovation and DHN optimisation. Construction of new pipes without changing pipe diameters and DHN pipe replacement after pipe diameters' optimisation taking into account the complete building renovation shows that there is a significant difference, and the last project is more acceptable.

The random buildings renovation and the parallel refurbishment of the DHN show a small dispersion of data (correlation coefficient $R=0.97$, (9)) as well as the fact that DHN heat loss reduction rate is independent of the district size and independent at a time when a district was built.

The uncertainty of the NPW influences the various parameters (variables) for reconstruction of DHN and is evaluated in "tornado" diagram and the regression equation. The greatest impact of the influence of NPW is on heating price variation which depends on fuel prices and varies within a wide range, and country's overall inflation rate. The obtained regression equation describes the interaction of NPW between several parameters: heating price inflation, overall inflation, network lifetime and revenue.

\section{References}

Asadi, E.; da Silva, M. G.; Antunes, C. H.; Dias, L. 2012. Multi-objective optimization for building retrofit strategies: a model and an application, Energy and Buildings 44: 81-87. http://dx.doi.org/10.1016/j.enbuild.2011.10.016

Basogul, Y.; Keçebas, A. 2011. Economic and environmental impacts of insulation in district heating pipelines, Energy 36(10): 6156-6164. http://dx.doi.org/10.1016/j.energy.2011.07.049

Biekša, D.; Šiupšinskas, G.; Martinaitis, V.; Jaraminiene, E. 2011. Energy efficiency challenges in multi-apartment building renovation in Lithuania, Journal of Civil Engineering and Management 17(4): 467-475. http://dx.doi.org/10.3846/13923730.2011.622408

Cox, M. G.; Harris, P. M. 2006. Uncertainty Evaluation. Middlesex University London National Physical Labora- tory [online], [cited 6 February 2013]. Available from Internet:

http://publications.npl.co.uk/npl_web/pdf/dem_es11.pdf.

EN ISO 13790:2008. 2008. Energy Performance of Buildings - Calculation of Energy Use for Space Heating and Cooling. Brussels: European Committee for Standardization. $165 \mathrm{p}$.

Dalla Rosa, A.; Christensen, J. E. 2011. Low-energy district heating in energy-efficient building areas, Energy 36(12): 6890-6899.

http://dx.doi.org/10.1016/j.energy.2011.10.001

Dalla Rosa, A.; Li, H.; Svendsen, S. 2011. Method for optimal design of pipes for low-energy district heating, with focus on heat losses, Energy 36(5): 2407-2418. http://dx.doi.org/10.1016/j.energy.2011.01.024

Directive 2010/31/EU of the European Parliament and of the Council of 19 May 2010 on the energy performance of buildings, Official Journal of the European Union 153(53): 13-35.

Dobersek, D.; Goricanec, D.; Krope, J. 2012. Calibration of pipe networks for district heating using the nonlinear optimisation method, International Journal of Nonlinear Sciences and Numerical Simulation 7(2): 225228.

Entrop, A. G.; Brouwers, H. J. H.; Reinders, A. H. M. E. 2010. Evaluation of energy performance indicators and financial aspects of energy saving techniques in residential real estate, Energy and Buildings 42(5): 618-629. http://dx.doi.org/10.1016/j.enbuild.2009.10.032

EPANET. 2013. United States environmental protection agency [online], [cited 28 January 2013]. Available from Internet:

http://www.epa.gov/nrmrl/wswrd/dw/epanet.html.

Jamsek, M.; Dobersek, D.; Goricanec, D.; Krope, J. 2010. Determination of optimal district heating pipe network configuration, WSEAS Transactions on Fluid Mechanics 3(5): 165-174.

Konstantinou, T.; Knaack, U. 2011. Refurbishment of residential buildings: a design approach to energyefficiency upgrades, Procedia Engineering 21: 666-675.

Li, X.-I.; Duanmu, L.; Shu, H. W. 2010. Optimal design of district heating and cooling pipe network of seawatersource heat pump, Energy and Buildings 42(1): 100-104. http://dx.doi.org/10.1016/j.enbuild.2009.07.016

Lithuanian District Heating Association. 2012a. Lietuvos centralizuoto šilumos tiekimo apžvalga 1990-2007 [Lithuanian district heating overview 1990-2007] [online], [cited 28 January 2013]. Available from Internet: http://bio-heat.eu/fileadmin/downloads/Deliverabels/1_ About_DH_in_Lithuania_resized.pdf.

Lithuanian District Heating Association. 2012b. Šilumos tiekimo bendroviu 2011 metū ūkinès veiklos apžvalga [Heat supply companies in 2011, the economic performance review] [online], [cited 28 January 2013]. Available from Internet: http://www.lsta.lt/files/statistika/2011_statistika.pdf.

Lithuanian District Heating Association. 2012c. Šilumos suvartojimo analize [Analysis of heating consumption]. [online], [cited 28 January 2013]. Available from Internet:

http://www.lsta.lt/lt/pages/apie-silumos-uki/silumos-su vartojimo-analize. 
Magrini, A.; Magnani, L.; Pernetti, R. 2012. The effort to bring existing buildings towards the A class: a discussion on the application of calculation methodologies, Applied Energy 97: 438-450.

Mehleri, E. D.; Sarimveis, H.; Markatos, N. C.; Papageorgiou, L. G. 2012. A mathematical programming approach for optimal design of distributed energy systems at the neighbourhood level, Energy 44(1): 96104. http://dx.doi.org/10.1016/j.energy.2012.02.009

Olsen, P. K.; Lambertsen, H.; Hummelshøj, R.; Bøhm, B.; Christiansen, C. H.; Svendsen, S.; Larsen, C. T.; Worm, J. 2008. A new low-temperature district heating system for low-energy buildings, in The 11th International Symposium on District Heating and Cooling, 31 August-2 September, 2008, Reykjavik, Iceland. 8 p.

OR/IM (Operations Management / Industrial Engineering Internet software by Paul A. Jensen). 2013. [Online], [cited 28 January 2013]. Available from Internet: www.me.utexas.edu/jensen/OR/IM/.

Ostfeld, A.; Salomons, E. 2004. Optimal layout of early warning detection stations for water distribution systems security, Journal of Water Resources Planning and Manangement 130(5): 377-385.

Paulsen, O.; Fan, J.; Furbo, S.; Thorsen, J. E. 2008. Consumer unit for low-energy district heating net, in The 11th international symposium on district heating and cooling, 31 August-2 September 2008, Reykjavik, Iceland. $7 \mathrm{p}$.

Persson, U.; Werner, S. 2011. Heat distribution and the future competitiveness of district heating, Applied
Energy 88(3): 568-576.

http://dx.doi.org/10.1016/j.apenergy.2010.09.020

Statistics Lithuania. 2013. Pagrindiniai šalies ekonominiai ir socialiniai raidos rodikliai [Main national economic and social development indicators] [online], [cited 28 January 2013]. Available from Internet: http://www.stat.gov.lt/lt/.

Svendsen, S.; Brand, M. 2010. Performance of low-temperature district heating systems for low-energy houses, in Final Conference "Low Exergy Systems for HighPerformance Building and Communities", 19-21 October, 2010. Presentation [online], [cited 28 January 2013]. Available from Internet: http://www.annex49. info/conference/vortraege/14_Svendsen.pdf.

STR 2.09.01:1998 Statybos techninis reglamentas. Šilumos tiekimo tinklai ir šilumos punktai [Building regulations. Heat distribution networks and substations]. Valstybès žinios, 1998-04-10, Nr. 34-923. 9 p.

Tol, H. I.; Svendsen, S. 2012. Improving the dimensioning of piping networks and network layouts in low-energy district heating systems connected to low-energy buildings: a case study in Roskilde, Denmark, Energy 38(1): 276-290. http://dx.doi.org/10.1016/j.energy.2011.12.002

Torío, H.; Schmidt, D. 2010. Development of system concepts for improving the performance of a waste heat district heating network with exergy analysis, Energy and Buildings 42(10): 1601-1609. http://dx.doi.org/10.1016/j.enbuild.2010.04.002

\footnotetext{
Algirdas KUPRYS. Doctor and Senior Research Associate of the Laboratory of Energy Systems Research of Lithuanian Energy Institute. PhD in Energy and Thermal Engineering (1982) of Lithuanian Energy Institute. Research interests: energy demand forecasting, analysis energy policy, security of energy supply and statistical data analysis.

Ramūnas GATAUTIS. Doctor and Research Associate of the Laboratory of Energy Systems Research of Lithuanian Energy Institute. PhD in Energy and Thermal Engineering (2005) of Lithuanian Energy Institute. Member of International Association for Energy Economics (IAEE) from 2002. Research interests: focus on CHP plants, district heating sector strategy, preparation of laws and the mathematical modelling.
} 